\title{
INDIAN WOMEN IN TECHNOLOGY: AN EMPIRICAL ANALYSIS OF ROLE CONFLICT
}

\author{
B. AISWARYA \\ Department of Management Studies \\ Sathyabama University Chennai \\ Tamil Nadu, India \\ G. RAMASUNDARAM \\ Department of Management Studies \\ St. Joseph's College of Engineering, Chennai \\ Tamil Nadu, India
}

\begin{abstract}
An important issue that our society has been facing in the recent past is the changing work and family roles of Indian women. Woman, today, function within multiple roles simultaneously operating in both work and family domains as a mother, spouse, housekeeper, as well as maintaining full-time employment outside the home. The relationship between these dual roles has thus become a topic of interest among organizational researchers. This study deals with selected antecedents and their influence on the role conflict among Indian women in technology. A sample size of 598 Indian women in technology was taken for the study and the result shows the occurrence of work-family conflict. Three predominant factors that influence the work-family conflict time-dimension are work exhaustion, work thought interference and perceived workload in the order of merit.
\end{abstract}

Keywords: Role conflict, employed women, information technology, dimensions of role conflict.

\section{Introduction}

Work and family are the two central domains that form the backbone of an individual's life (Howard,1992). They are work domain (employment) and non-work domain (family). These two inevitable institutions, namely work and family have historically coexisted simultaneously as discrete spheres in one's life. But this separation between work and life began to fade with changes in societal demographics.

The traditional nuclear family where the husband works outside and the wife cares for the home and children is the system which no longer applies to the majority of families in the recent few decades. There has been an accelerated influx of women into paid employment roles that has taken place in the recent past.

Now more women are entering the labour workforce which was once considered to be meant for men only. A majority of women want everything that men have traditionally wanted - success, power, status, money, as well as committed relationship, love, children and happiness. In most studies, researchers have found that carrying out these dual roles often 
leads to work-family conflict for both men and women. The profound demographic trends have elevated the need to understand and manage the interface between work and family (Fraser, 2001).

\section{About the Industry}

The Indian Information Technology and Business Processing Outsourcing (IT-BPO) Industry has emerged as the largest private sector employer in the country, with direct employment of 2.23 million professionals and indirect employment of over eight million people in different industry sectors. While the percentage of women in the IT -BPO workforce at the entry level is commensurate with graduate profiles anecdote evidence suggests that this is not the case at middle and senior management positions. Skill sets and designations in the organizational hierarchy indicate that women contribute significantly to the success of companies and the IT-BPO industry as a whole.

Table 1

Employment in Information Technology Industry in India (in millon)

\begin{tabular}{lcccccccc}
\hline Year/ Item & $2001-02$ & $2002-03$ & $2003-04$ & $2004-05$ & $2005-06$ & $2006-07$ & $2007-08$ & $2008-09$ \\
\hline $\begin{array}{l}\text { IT Services and } \\
\text { exports }\end{array}$ & 0.17 & 0.21 & 0.30 & 0.39 & 0.51 & 0.69 & 0.86 & 0.92 \\
BPO Exports & 0.11 & 0.18 & 0.22 & 0.32 & 0.42 & 0.55 & 0.70 & 0.79 \\
Domestic Market & 0.25 & 0.29 & 0.32 & 0.35 & 0.38 & 0.38 & 0.45 & 0.50 \\
$\begin{array}{l}\text { Total } \\
\text { Employment }\end{array}$ & 0.52 & 0.67 & 0.83 & 0.06 & 0.29 & 0.62 & 0.01 & 2.21 \\
\hline
\end{tabular}

Source. National Association of Software and Services Companies (NASSCOM Report, 2009).

The IT-ITES industry's contribution to the national GDP is estimated to increase from 6.0 per cent in 2008 - 09 to 6.1 per cent in 200910.The total number of IT and ITES -BPO professionals employed in India have grown from 0.52 million in 2001- 02 to 2010 million in $2008-09$.

In addition, about one fifth of the female employees in the IT-BPO industry are at the managerial level or above indicating the numerous opportunities provided to them by the industry. The increase can be attributed to the gender agnostic requirements of the industry and the flexible work environment provided by the IT-BPO companies.

\section{Problem Statement}

Many studies have shed light upon the correlates of work-family conflict. Although the term work-family conflict is used frequently in the business and psychological literature (Frone, 2003) a comprehensive study including the antecedents, and its impact on the dimensions has not been applied so far; subsequent measurement approaches have also varied widely in the previous studies.

Although one can generally accept the occurrence of work-family conflict resulting from various causes, the order in which the selected antecedents which have an impact on 
the dimensions of role conflict has not been evidenced so far.

\section{Objectives of the Study}

- To study the various causes of workfamily conflict.

- To study the influence of the causes on the time-dimension of role conflict.

\section{Review of Literature}

\section{Work-Life Conflict}

Greenhaus and Beutall (1985) defined work and family conflict as a form of interrole conflict in which the role pressures from the work and family domains are mutually incompatible in some respects. Work and family are two central domains in most adults' lives.

Researchers in this area have distinguished between two types of work-family conflict, work interfering with the family and family interfering with work. The second work-family conflict strain-based conflict arises when strain in one role affects one's performance in another role. The last type is behaviour-based conflict which refers to incompatibility between the behavioural patterns that are desirable in the two domains.

Some of the more prevalent antecedents and outcomes of work-life conflict identified in the literature include role commitment, role salience and satisfaction parenting (Rousseau, 1984), marriage and spousal support (Barnette \& Marshall, 1991) and supervisory and company support (Bowen, 1988). Greenhaus and Beutall (1985) identified three major types of workfamily conflict. The first is time-based; the time spent on role performance in one domain often the precludes time spent in the other domain. The second work-family conflict is strain-based; the conflict arises when strain in one role affects one's performance in another role. The last type is behaviour-based conflict which refers to incompatibility between the behavioural patterns that are desirable in the two domains.

\section{Causes of Work-Family Conflict}

There are several causes that influence the work-family conflict of employed women. Eight variables have been considered for the study, namely organizational commitment, organizational climate, job involvement, work exhaustion, work-thought interference, perceived work and family demand, job autonomy and family involvement. The relevant literature is explained briefly.

\section{Organizational Commitment}

Organizational commitment refers to the extent to which employees like and feel being a part of the organization for which they work. It is the relative strength of an individual's identification with and the involvement in a particular organization (Mowday et al., 1982).

Work-life balance is positively associated with organizational commitment. This finding is consistent with work-family conflict. Research found that employees who experienced excess work to family-conflict and family to workconflict will be less committed to their work organization (Allen et al., 2000).

Grover and Crooke (1985) studied multiple family responsive policies together and found that employees with access to more of these benefits showed greater commitment and lower intentions to leave. Their study also supported the idea that flexible working hours offered by organizations influenced the organizational commitment of employees.

\section{Organizational Climate}

Organizational climate is defined as the recurring patterns of behaviour, attitudes and feelings 
that characterize life in the organization. It is more related to atmosphere tone and ethos. Organizational climate is a relatively new concept and refers to the extent to which work environment is supportive with regards to employees' work and family needs (Allen, 2001).

These individual perceptions are often aggregated or collected for analysis and understood at the team or group level, or the divisional, functional, or overall organizational level. Since positive work-family climate is a specific form of organizational support and it constitutes a stress factor at work, we can conclude that supportive work-family climate would alleviate the negative impact of work-family conflict on the job-related attitudes of the employees; thus improving the productivity of the organization (Thompson et al., 1999).

\section{Work Exhaustion}

Work exhaustion is about the work itself and reflects a salient frustration about job outcomes (Moore, 2000).Employees will likely decrease their organizational commitment as their work exhaustion increases because they will lose faith that the company can take care of them by providing an acceptable worklife.

Research has linked perceived-work-interference family to increased burn out. Moreover, it is stated that perceived conflict from family responsibilities interfering with work will also be associated with emotional exhaustion (Bacharach, Bamberger, \& Conley, 1991).

\section{Work-thought Interference}

Work-thought interference is the inability to stop dwelling on work matters or simply an inability to stop thinking about work. An unforeseen and illogical consequence of a single-sided segmentation has been the amalgamation or blurring of the borders between home and work for the worker, enhancing the intrusion of the work-role into the non-work domain (Louis \& Sutton, 1991).
Thus, the work-thought interference leads to identifiable behavioural manifestations and social repercussions. It may otherwise be described as the failure of one's role transition in border-crossing behaviour. In case of career women, post-child bearing is an especially painful manifestation of work's all consuming nature (Sarason et al., 1996).

\section{Perceived Work and Family Demand}

Perceived demand is a global perception of the level and intensity of responsibility within the family and the work domains. It is posited that perceived demand will be identifiable to researchers and perceived by the individuals.

Voydanoff (1988) contended that both work and family demand concepts included variables such as number of hours worked, schedule role conflict, role ambiguity, role overload, stress from work, marital status, spouses' working hours, number of children and age of children. Finally, many of these measures are indicators for demand such as hours worked rather perceived demand levels.

\section{Job Autonomy}

Job autonomy is defined as "the degree to which the job provides substantial freedom, independence and discretion to the individual in scheduling the work and in determining the procedure to be used in carrying it out (Ilgen \& Hollenbeck, 1992).

Another perspective of job autonomy as stated by Ettner and Grzywacz (2001) was that workers who reported higher levels of dissatisfaction with working conditions and lack of autonomy had more negative health effects. Thus job autonomy has an impact not only on the organizations and family but also on the health of the employee.

\section{Job Involvement}

The job involvement represents the degree to which the individual's job is central to his/her self-concept and identity. Lodhal and Kejner 
(1965) conceptualized job involvement as an internalization of work values that an individual derives self-esteem from the involvement in the job.

The fact that women still assure greater responsibility for family may help explain their lesser degree of work involvement (Spence, 1985). Paradoxically, married women individuals generally report greater levels of work involvement probably due to their family responsibilities.

\section{Family Involvement}

Family involvement of the employed women demonstrates her participation in the household activities in lieu of the paid outside activities. Although Brett and Yogev (1988) concluded that family involvement was not significantly correlated with restructuring, Karambayya and Reilly (1992) determined that family involvement correlated positively with work restructuring for both the husbands and the wives in their dual earner sample. Moreover family involvement is the impact of those family roles on an individual's image, self -concept and commitment to the roles.

\section{Methods}

Research Design: The design applied in the study is descriptive correlation research design. It is appropriate to use this method in this research to describe the relationship among different variables.

Questionnaire: A set of questions was adopted from the already existing tested questionnaire to satisfy the objective of the study with the help of previous studies and literature review for the selected variables.

The adopted instruments for the study as variables for the causes are organizational commitment
(Mowday, Steers, \& Porter, 1979), job autonomy (Beehr, 1976), job involvement (Lodhal \& Kejner, 1965), family involvement (Lodhal \& Kejner, 1965), organizational climate (Patterson et al., 2005), perceived workload (Moore, 2000), perceived family demand (Sudman 1982), workthought interference (Friedmann \& Greenhaus, 2000) and work exhaustion (Moore, 2000).

Sampling: In this study, population refers to women employees in the IT and ITES firms located in Chennai city. As the population size is very large ( 0.21 million), the convenience sample technique was adopted for selecting the sample units. The sample units of this study consisted of married and unmarried employed women in the IT industry in Chennai city. A thousand questionnaires were distributed to the respondents but only 735 were received after continuous follow-up. Among the collected questionnaires, only 598 completed questionnaires were taken into account for the research.

\section{Findings}

The first factor comprises five statements with the eigen value of 7.687. The core of statements loading factor varies from 0.785 to 0.695 . This factor accounts for the variance of 9.335 per cent with the reliability co-efficient of 0.851 .

The statements in the table have similarities in terms of the commitment of an employee towards the organization. All the statements describe the affinity and attachment the individual can have upon his organization. Thus, this factor is named as organizational commitment.

The second factor consists of five statements with the eigen value of 4.120 and explains 8.486 per cent of variance. The loading value of these statements varies from 0.718 to 0.495 . All the statements have a meaning related to the good atmosphere of the organization. Hence it is named as organizational climate with the reliability co-efficient of 0.847 . 
Table 2

Factor 1: Organizational Commitment

\begin{tabular}{|c|c|c|c|c|c|}
\hline S.N & Statement & Loading & $\begin{array}{l}\text { Eigen } \\
\text { value }\end{array}$ & $\begin{array}{l}\% \text { of } \\
\text { variance }\end{array}$ & Cronbach alpha \\
\hline 1 & $\begin{array}{l}\text { I am extremely glad to have chosen this } \\
\text { organization among all other organizations to } \\
\text { work for. }\end{array}$ & .785 & & & \\
\hline 2 & $\begin{array}{l}\text { For me, this is the best possible organization } \\
\text { to work. }\end{array}$ & .767 & & & \\
\hline 3 & $\begin{array}{l}\text { My organization inspires the very best } \\
\text { towards job performance. }\end{array}$ & .749 & 7.687 & 9.335 & 0.851 \\
\hline 4 & $\begin{array}{l}\text { I really care about the success of my } \\
\text { organization. }\end{array}$ & .731 & & & \\
\hline 5 & $\begin{array}{l}\text { I am willing to put in extra efforts for the } \\
\text { success of the organization. }\end{array}$ & .695 & & & \\
\hline
\end{tabular}

Table 3

Factor 2: Organizational Climate

\begin{tabular}{llllll}
\hline S.N & \multicolumn{1}{c}{ Statement } & Loading & $\begin{array}{c}\text { Eigen } \\
\text { value }\end{array}$ & $\begin{array}{c}\text { \% of } \\
\text { variance }\end{array}$ & $\begin{array}{c}\text { Cronbach } \\
\text { alpha }\end{array}$ \\
\hline 1 & $\begin{array}{l}\text { My organization takes pride in my accomplishment } \\
\text { at work. }\end{array}$ & .718 & & & \\
2 & My organization helps me when I have a problem. & .691 & & & \\
3 & $\begin{array}{l}\text { My organization really cares for my well-being. } \\
4\end{array}$ & .672 & 4.120 & 8.486 & 0.847 \\
& $\begin{array}{l}\text { My organization helps me to perform my job to the } \\
\text { best of my ability. }\end{array}$ & .551 & & & \\
& $\begin{array}{l}\text { My organization respects every employee as a part } \\
\text { of its culture. }\end{array}$ & .495 & & & \\
\hline
\end{tabular}

Factor three is represented by the four statements mentioned in the above table. The eigen value for this factor is 2.950 and it accounts for 8.029 per cent of variance. The loading factor for the statements ranges

from 0.811 to 0.684 with the Cronbach alpha value 0.814 . All the above statements exhibit physical and emotional drain because of work. Therefore, it is appropriate to label the factor as work exhaustion.

Factor four consists of four statements and has the eigen value of 2.144 with 7.818 per cent of variance. The highest loading factor is 0.815 and the lowest is 0.519 and 
Table 4

Factor 3: Work Exhaustion

\begin{tabular}{clcccc}
\hline S.N & \multicolumn{1}{c}{ Statement } & Loading & $\begin{array}{c}\text { Eigen } \\
\text { value }\end{array}$ & $\begin{array}{c}\% \text { of } \\
\text { variance }\end{array}$ & $\begin{array}{c}\text { Cronbach } \\
\text { alpha }\end{array}$ \\
\hline 1 & I feel burned out from work. & .811 & & & \\
2 & $\begin{array}{l}\text { I feel fatigued when I get up in the morning and have to } \\
\text { face another day on the job. }\end{array}$ & .809 & 2.950 & 8.029 & 0.814 \\
3 & I feel exhausted physically at the end of the work day. & .697 & & & \\
4 & I feel emotionally drained from my work. & .684 & & & \\
\hline
\end{tabular}

Table 5

Factor 4: Perceived Workload

\begin{tabular}{clcccc}
\hline S.N & \multicolumn{1}{c}{ Statement } & Loading & $\begin{array}{r}\text { Eigen } \\
\text { value }\end{array}$ & \% of variance & Cronbach alpha \\
\hline 1 & My job requires a lot of effort. & .815 & & & \\
2 & My job requires all of my attention. & .814 & & & \\
3 & My work requires a lot from me. & .781 & 2.144 & 7.818 & \\
4 & I am given a lot of work. & .519 & & & \\
\hline
\end{tabular}

Table 6

Factor 5: Family Involvement

\begin{tabular}{llcccc}
\hline S.N & \multicolumn{1}{c}{ Statement } & Loading & Eigen value & $\%$ of variance & Cronbach alpha \\
\hline 1 & $\begin{array}{l}\text { The major satisfaction in my life } \\
\text { comes from my family life. }\end{array}$ & .800 & & & \\
2 & $\begin{array}{l}\text { The most important things that happen } \\
\text { to me involve my family. }\end{array}$ & .775 & 1.770 & 7.185 & 0.781 \\
3 & $\begin{array}{l}\text { I am very involved in my family. } \\
4\end{array}$ & $\begin{array}{l}\text { I am really a perfectionist in my home/ } \\
\text { family life. }\end{array}$ & .653 & & \\
\hline
\end{tabular}

the reliability co-efficient is measured as 0.817. All the statements which are grouped together in this category give the meaning of workload that is perceived by the employees Hence, this factor is labelled as perceived workload. 
The next factor consists of five statements giving the meaning of individual involvement with family activities. Out of the five statements the loading factor of less than 0.5 is suppressed; barring one statement the rest range from 0.800 to 0.653 with the eigen value of 1.770 and accounts for 7.185 per cent of variance.

The reliability co-efficient is 0.781 . Since it denotes involvement in family activities this variable is called family involvement.

The next factor comprises five statements with the eigen value of 1.469 and the reliability coefficient of 0.748 . The loading factor for the above statements ranges from 0.779 to 0.515 with 6.969 per cent variance.

All these statements signify the interfering thoughts of work-related activities even when out of work. Therefore, this factor is termed as work-thought interference.

The next factor contains three statements with the loading factor ranging from 0.817 to 0.706 , with the eigen value of 1.435 and accounts for 6.281 per cent of variance. The reliability co-efficient measured is 0.793 . All the three statements talk about the familial demand of an employee. Hence, the name of the variable is perceived family demand

Table 7

Factor 6: Work-thought Interference

\begin{tabular}{|c|c|c|c|c|c|}
\hline S.N & Statement & Loading & $\begin{array}{l}\text { Eigen } \\
\text { value }\end{array}$ & $\begin{array}{c}\% \text { of } \\
\text { variance }\end{array}$ & $\begin{array}{l}\text { Cronbach } \\
\text { alpha }\end{array}$ \\
\hline 1 & $\begin{array}{l}\text { Even when away from work, I find it hard to let go } \\
\text { of work-related feelings. }\end{array}$ & .779 & \multirow{5}{*}{1.469} & \multirow{5}{*}{6.969} & \multirow{5}{*}{0.748} \\
\hline 2 & $\begin{array}{l}\text { When away from work I find myself rehearsing } \\
\text { work-related scenarios in my mind. }\end{array}$ & .770 & & & \\
\hline 3 & $\begin{array}{l}\text { When outside of work I have a tendency to discuss } \\
\text { work more than anything else. }\end{array}$ & .746 & & & \\
\hline 4 & Thoughts about work disturb my sleep. & .629 & & & \\
\hline 5 & $\begin{array}{l}\text { I am preoccupied with work-related duties while } \\
\text { away from work. }\end{array}$ & .515 & & & \\
\hline
\end{tabular}

Table 8

Factor 7: Perceived Family Demand

\begin{tabular}{rlllll}
\hline S.N & \multicolumn{1}{c}{ Statement } & Loading & $\begin{array}{c}\text { Eigen } \\
\text { value }\end{array}$ & $\begin{array}{c}\% \text { of } \\
\text { variance }\end{array}$ & $\begin{array}{c}\text { Cronbach } \\
\text { alpha }\end{array}$ \\
\hline 1 & My home life requires a lot of effort. & .817 & & & \\
2 & I have to work hard on family-related activities. & .773 & 1.435 & 6.281 & 0.793 \\
3 & My family requires all of my attention. & .706 & & & \\
\hline
\end{tabular}


Table 9

Factor 8: Job Autonomy

\begin{tabular}{clcccc}
\hline S.N & \multicolumn{1}{c}{ Statement } & Loading & $\begin{array}{c}\text { Eigen } \\
\text { value }\end{array}$ & $\begin{array}{c}\% \text { of } \\
\text { variance }\end{array}$ & $\begin{array}{c}\text { Cronbach } \\
\text { alpha }\end{array}$ \\
\hline 1 & $\begin{array}{l}\text { I set my own schedule for completing } \\
\text { assigned tasks. }\end{array}$ & .812 & & & \\
2 & $\begin{array}{l}\text { I have the authority to initiate projects in my } \\
\text { job. }\end{array}$ & .673 & 1.328 & 5.857 & 0.777 \\
$3 \quad \begin{array}{l}\text { I have a lot of freedom to decide on how to } \\
\text { do my job. }\end{array}$ & .663 & & & \\
\hline
\end{tabular}

This factor which comprises four statements barring one with the loading factor of less than 0.45 . So, only three statements with the loading factor ranging from 0.812 to 0.663 are taken into consideration. The eigen value is 1.328 with 5.857 per cent variance. The reliability co-efficient is 0.77 . The above statements denote the freedom and the authority in the job that an employee can enjoy. Job autonomy is the suitable term for this factor.

Table 10

Factor 9: Job Involvement

\begin{tabular}{clcccc}
\hline S.N & \multicolumn{1}{c}{ Statement } & Loading & $\begin{array}{c}\text { Eigen } \\
\text { value }\end{array}$ & $\begin{array}{c}\% \text { of } \\
\text { variance }\end{array}$ & $\begin{array}{c}\text { Cronbach } \\
\text { alpha }\end{array}$ \\
\hline 1 & I am really a perfectionist in my work. & .620 & & & \\
2 & I am very much involved personally in my work. & .588 & & & \\
3 & The major satisfaction in my life comes from my job. & .561 & 1.219 & 5.232 & 0.693 \\
4 & $\begin{array}{l}\text { The most important things that happen to me involve my } \\
\text { work. }\end{array}$ & .553 & & & \\
\hline
\end{tabular}

The last factor comprises five statements signifying the individual's involvement in the job. One statement with the loading factor of less than 0.45 is suppressed. For the rest of the four statements the loading value ranges from 0.620 to 0.553 with the eigen value of 1.209 and 5.232 per cent of variance. The reliability co-efficient is 0.629 . This factor is labelled as job involvement because all the statements above give a similar meaning.

\section{Segmentation of the Causes of Role Conflict}

In order to group the statements based on the causes for work-life conflict, explorative factor analysis was used. The KMO Bartletts test was used for measuring sampling adequacy. 
Table 11

KMO and Bartlett's Test

Kaiser-Meyer-Olkin Measure of Sampling Adequacy

0.841

Bartlett's Test of Sphericity, Approx. Chi-Square

$1.009 \mathrm{E} 4$

Degree of freedom

666

Significance

.000

The results in the table show that the sample size of this study is adequate to conduct factor analysis. Moreover, the correlation between the variables under each factor is significantly strong and that is justified with the chi-square value in the table.

Around thirty-seven statements, barring three, are grouped under nine factors. For extraction purpose, principle component analysis is applied. The Varimax rotation method is needed for rotating the matrix. Factors, which score the eigen value of more than one are only taken for analysis purpose and statements with the loading factor of less than 0.5 are suppressed.

Table 12

Reliabilty Values of the Variables

Causes of work family conflict

Organisation commitment

0.851

0.762

Job autonomy

0.809

Job involvement

0.898

Family involvement

0.847

Organisational climate

0.817

0.793

0.748

0.814

Work exhaustion

0.923
The above table represents the reliability values of the variables taken for the study. The reliability values of less than 0.7 have been rejected and those representing more have been accepted. 
The reliability values show the consistency with which the said variables can be used for the research purpose.

\section{Influence of Causes on Role Conflict}

Based on previous literature it has been found that role conflict is caused by many factors. However, the predominant factors are organizational commitment, organizational climate, work exhaustion, perceived workload, perceived family demand, family involvement and job autonomy. For understanding the significance of influence and the level of influence of these factors, stepwise regression was employed. As the dimension of role conflict is divided into time, strain and behaviour for each dimension, the regression line is estimated.

Table 13

Influence of Causes on Work-family Conflict-time

\begin{tabular}{ccccccccccc}
\hline \multicolumn{10}{c}{ Model Summary } \\
\hline Model & $\mathrm{R}$ & R Square & $\begin{array}{c}\text { Adjusted R } \\
\text { Square }\end{array}$ & Std. Error & \multicolumn{5}{c}{ Change Statistics } \\
\cline { 5 - 10 } & & & & & $\begin{array}{c}\text { R Square } \\
\text { change }\end{array}$ & F change & df1 & df2 & Sig. F \\
\hline 1 & $.577^{\mathrm{a}}$ & .333 & .332 & .65642 & .333 & 297.679 & 1 & 596 & .000 \\
2 & $.622^{\mathrm{b}}$ & .387 & .385 & .62988 & .054 & 52.275 & 1 & 595 & .000 \\
3 & $.643^{\mathrm{c}}$ & .413 & .410 & .61695 & .026 & 26.199 & 1 & 594 & .000 \\
\hline
\end{tabular}

Predictors : Constant, work exhaustion.

Predictors : Constant, work exhaustion, work-thought

interference.

Predictors : Constant, work exhaustion, work-thought interference, perceived workload.

Dependent

variable : Work -family conflict-time.

The output of stepwise regression is explained with the help of three regression equations that have been evolved by incorporating only the significant independent variables one by one. It is evident from $\mathrm{R}$ square and adjusted $\mathrm{R}$ square values in the table that the level variance explained by the independent variables is increasing significantly due to the successive addition of causes. Totally 41 per cent of variance of timedimension of work-family conflict is explained by work exhaustion, work-thought interference and perceived workload. Among them, the highest variance is for work exhaustion (33.3 per cent) followed by work-thought interference (5.4 per cent) and perceived workload (2.6 per cent).

Though there are many variables influencing the work-life conflict, only six variables are considered for the study. Among the six taken for the study, the variables that influence the work family conflict the most is listed in the order of importance. Work exhaustion influences the most, followed by work-thought interference and perceived workload. The total percentage 
of contribution made by the three variables is 41.0 per cent. The remaining variables are insignificant and therefore not reflected in the analysis.

Table 14

Coefficients and Collinearity Statistics

\begin{tabular}{|c|c|c|c|c|c|c|c|c|}
\hline & \multirow[t]{2}{*}{ Model } & \multicolumn{2}{|c|}{$\begin{array}{l}\text { Unstandardized Co- } \\
\text { efficients }\end{array}$} & \multirow{2}{*}{$\begin{array}{c}\begin{array}{c}\text { Standardized } \\
\text { Co-efficients }\end{array} \\
\text { Beta }\end{array}$} & \multirow[t]{2}{*}{$\mathrm{t}$} & \multirow[t]{2}{*}{ Sig } & \multicolumn{2}{|c|}{ Collinearity Statistics } \\
\hline & & B & Std. Error & & & & Tolerance & VIF \\
\hline \multirow{3}{*}{1} & Constant & 1.601 & .108 & & 14.830 & .000 & & \\
\hline & Wrk Extn & 0.561 & .033 & .577 & 17.253 & .000 & 1.000 & 1.000 \\
\hline & Constant & 1.166 & .120 & & 9.732 & .000 & & \\
\hline \multirow[t]{3}{*}{2} & Wrk Extn & .500 & .032 & .514 & 15.457 & .000 & .931 & 1.074 \\
\hline & Wrk Thgt Int & .249 & .034 & .240 & 7.230 & .000 & .931 & 1.074 \\
\hline & Constant & .553 & .168 & & 3.297 & .001 & & \\
\hline \multirow{3}{*}{3} & Wrk Extn & .460 & .033 & .473 & 14.109 & .000 & .879 & 1.138 \\
\hline & Wrk Thgt Int & .242 & .034 & .234 & 7.170 & .000 & .930 & 1.075 \\
\hline & Prcd Wrk load & .199 & .039 & .167 & 5.118 & .000 & .933 & 1.072 \\
\hline
\end{tabular}

The unstandardised co-efficients reveal that the highest level of influence is contributed by work exhaustion. Every one unit change is work exhaustion leads to 0.46 unit change in work-family conflict. However, the contribution of work-thought interference and perceived workload to one unit's change of work-family conflict are 0.242 and 0.199 respectively.

\section{Results and Discussion}

\section{Worklife-Conflict-Time}

From the unstandardised co-efficient values we can infer that the highest level of influence is contributed by work exhaustion. Every single unit of change in the independent variable will cause equally important changes in the dependent variable with the magnitude measured through the co efficient. The measures of co-efficient for independent variables are work exhaustion (0.343), job autonomy (0.147), perceived workload (0.138), work-thought interference (0.089), organization climate (0.137) and job involvement (-0.130).

The standardized errors for these co-efficient estimates are very minimum. Instances of higher degrees of multicollinearity are reflected in lower tolerance values and high variable inflation factor values. As mentioned, the tolerance factor which is also found to be in a decreasing trend states the unexplained portion of the dependent variable through the respective independent variable which is very less. 


\section{Conclusion}

Though there are several causes for the occurrence of work-family conflict, three predominant factors that influence work-family conflict - timedimension are work exhaustion, work-thought interference and perceived workload in the order of merit. It is work exhaustion that influences the time dimension of work-family conflict the highest, followed by work-thought interference and perceived workload the least. The influence of organizational commitment, organizational climate, perceived family demand, family involvement, job autonomy and job involvement is less and not considered as a cause for the occurrence of worklife-conflict time.

\section{References}

Allen. S. (2001). What is work for? The right to work and the right to be idle. In Richard K. Brown (Ed.). The Changing Shape of Work. New York: St. Martin's Press.

Allen, T. D., Herst, D. E. L., Bruck, C. S., \& Sutton, M. (2000). Consequences associated with work-to-family conflict: A review and agenda for future research. Journal of Occupational Health Psychology, 5, 278-308.

Barnett, R. C., \& Marshall, N. L. (1991). The relationship between women's work and family roles and subjective wellbeing and psychological distress. In Frankenhaeuser, M., Lundbert, U., \& Chesney, M. (Eds.), Women, Work and Health: Stress and Opportunities (pp.111136). New York: Plenum.

Beehr, T. (1976). Perceived situational moderators of the relationship between subjective role ambiguity and role strain. Journal of Applied Psychology, 61, 35-40.

Brett, J. M., \& Yogev, S. (1988). Restructuring work for family: How dual-earner couples with children manage. In Elizabeth
Goldsmith, B. (Ed.),Work and family: Theory, research and applications (pp. 159-174). Newbury Park, CA: Sage Publications.

Ettner, S. L., \& Grywacz, J. G. (2001). Worker's perceptions of how jobs affect health: A social ecological perspective. Journal of Occupational Health Psychology, 6, 101113.

Friedman, S. D., \& Greenhaus, J. H. (2000). Work and family: Allies or enemies? What happens when business professionals confront life choices. New York: Oxford University Press.

Greenhaus, J. H., \& Beutall, N. J. (1985). Sources of conflict between work and family roles. Academy of Management Review, 10, 76-88.

Grover, S. L., \& Crooker, K. J. (1995). Who appreciates family responsive human resource policies: The impact of familyfriendly policies. Personnel Psychology, 40, 271-288.

Ilgen, D. R., \& Hollenbeck, J. R. (1992). The structure of work: Job design and roles. In M. D. Dunnette \& L. M. Hough (Eds.), Handbook of Industrial and Organisational Psychology, 2, 65-207.

Karambayya, R., \& Reilly, A. H. (1992). Dualearner couples: Attitudes and actions in restructuring work for family. Journal of Organizational Behaviour, 13, 585-601.

Lodhal, T. M., \& Kejner, M. (1965). Definition and measurement of job involvement. Journal of Applied Psychology, 49, 2433.

Mowday, R. T., Steers, R. M., \& Porter, L. W. (1979). The measurement of organizational commitment. Journal of Vocational Behaviour, 14, 224-247.

Mowday, R., Porter, L., \& Steers, R. (1982). Employee organizational linkages: The psychology of commitment, absenteeism, and turnover. New York: Academic Press. 
Patterson, M. G., West, M. A., Shackelton, V. J., Dawson, J. F., Lawthom, R., Maitlis, S., Robinson, D. L., \& Wallace, A. M. (2005). Validating the organizational climate measure: Links to managerial practices, productivity and innovation. Journal of Organizational Behaviour, 26, 379-408.
Spence, T. J. (1985). Achievement American style: The rewards and costs of individualism, American Psychologist, 40, 12.

Sudman, S. (1982). Asking questions. San Francisco: Jossey Bass Publishers. 